\title{
PENDAMPINGAN PEMBUATAN SISTEM HIDROPONIK DAN PENGOLAHAN SAMPAH ORGANIK
}

\section{MENTORING IN BUILDING HYDROPONIC SYSTEMS AND ORGANIC WASTE PROCESSING}

\author{
${ }^{1)}$ Sulistyawati, ${ }^{2)}$ Muchsin Maulana, ${ }^{3)}$ Fatwa Tentama, ${ }^{4}$ Surahma Asti M, ${ }^{5)}$ Tri Wahyuni Sukesi \\ ${ }^{1,2,4,5)}$ Fakultas Kesehatan Masyarakat, Universitas Ahmad Dahlan Yogyakarta. \\ Jl. Prof. DR. Soepomo SH, Warungboto, Umbulharjo, Kota Yogyakarta, Daerah Istimewa \\ Yogyakarta 55164 \\ ${ }^{3)}$ Fakultas Psikologi, Universitas Ahmad Dahlan Yogyakarta, Jalan Kapas No.9, Semaki, \\ Umbulharjo, Semaki, Umbulharjo, Kota Yogyakarta, Daerah Istimewa Yogyakarta 5516 \\ email: sulistyawatisuyanto@gmail.com
}

\begin{abstract}
ABSTRAK
Dusun Jatikuning dan Soka merupakan suatu daerah di Ngoro-oro, Patuk, Gunungkidul. Daerah ini memiliki lahan pertanian yang luas namun mayoritas bersifat tadah hujan karena keterbatasan air. Di wilayah tersebut melimpah limbah-limbah pertanian saat musim panen seperti sekam padi. Kondisi perekonomian warga masyarakat yang di wilayah tersebut sangat tergantung pada musim panen yang tadah hujan tersebut, sehingga saat musim kemarau warga di wilayah mitra kesulitan mempertahankan stabilitas perekonomian keluarganya. Oleh sebab itu program ini bertujuan transfer teknologi hidroponik dan pengolahan sampah organik dengan tujuan untuk mendukung perekonomian keluarga.Metode yang digunakan dalam program ini adalah pendampingan masyarakat melalui penyuluhan dan pelatihan dalam pemanfaatan hidroponik dan pengelolaan sampah organikmelalui: sosialisasi program, penyuluhan dan praktek pembuatan media tanam hidroponik, penyuluhan dan praktek pembuatan pupuk organic, penyuluhan pembuatan briket bioarang dan monitoring dan evaluasi. Luaran dari program ini adalah:peningkatan pengetahuan dan, peningkatan ketrampilan mitra dalam pembuatan media tanam hidroponik dan pengolahan sampah organic melalui pemberdayaan masyarakat.
\end{abstract}

Kata kunci : Pendampingan, Hidroponik, Pupuk Organic, Pemberdayaan masyarakat

\begin{abstract}
Jatikuning and Soka are the hamlets which part of Ngoro-oro village, Patuk subdistrict, Gunungkidul, Yogyakarta. This area is an agriculture area, but the majority of them do not have regular irrigation. The area gets irrigation when the rainy season. In that region, a lot of agriculture waste that do not process appropriately, such as rice husk. Considering the economic condition of this area, people have good financial when they on the harvest time then they will face a hard situation in the dry season. Accordingly, this program aims to transfer hydroponic technology and waste management which purpose to support family economically. This program applied community empowerment through counseling and training in utilizing hydroponics and managing organic waste through program socialization, counseling and training on the hydroponic system, counseling and training on organic waste management, counseling and training on "briket bioarang", monitoring and evaluation. The output of this program isknowledge improvement and, skill improvement in developing the hydroponic system and waste management through community empowerment
\end{abstract}

Keywords: Mentoring, Hydrophonic, Organic Waste, Empowerment, Society 


\section{PENDAHULUAN}

Dusun Soka dan Jatikuning merupakan dua dusun yang terletak di Desa Ngorooro, Patuk, Gunungkidul, Daerah Istimewa Yogyakarta (DIY). Dusun Jatikuning dan Dusun Soka, berlokasi sekitar $40 \mathrm{~km}$ dari pusat Propinsi DIY. Luas wilayah dusun Jatikuning adalah 134.5896 hektar, meliputi sawah 17.9517 hektar, Tegal 50.1470 hektar, pekarangan 54.6340 hektar, dan lain-lain (makam, jalan, kali, sungai, lapangan voli 11.8570 hektar. Dusun jatikuning ini terdiri dari 6 RT dan 2 RW dan terdapat 765 jiwa. Dusun Soka memiliki luas wilayah 93.2Ha2, terdiri dari 2 RW, RW 08 terdiri dari 3 RT yaitu RT 29, RT 30, RT 31, Dan RW 09 terdiri dari 3 RT yaitu RT.32, RT.33, RT.34 terdiri dari 905 jiwa.

Dua dusun ini memiliki beberapa potensi antara lain wilayah yang luas dan warga yang terbuka terhadap perkembangan ilmu pengetahuan. Warga di dusun mitra memiliki berbagi macam mata pencaharian seperti PNS (Pegawai Negeri Sipil), perangkat desa, pegawai swasta, wiraswasta, tukang kayu, tukang batu, tukang becak, supir, petani, dan pedagang. Namun mayoritas penduduk di dusun mitra mayoritas mata pencahariannya adalah petani. Didukung dengan wilayah yang luas, pertanian di lokasi ini berkembang walaupun mengandalkan pertanian tadah hujan. Pemanfaatan sumberdaya lokal sebagai pendukung pertanian telah diinisiasi oleh Bank Sampah yang ada di wilayah tersebut. Bank sampah menjadi pusat kegiatan yang terkait dengan pengolahan sampah dan pertanian hydroponik di wilayah tersebut

Selain beberapa kelebihan diatas, masyarakat di dusun ini menghadapi beberapa kelemahan antara lain: pertanian yang hanya bisa dilakukan semusim, sehingga perekonomian warga terkadang menjadi tidak stabil karena tidak ada hasil panen. Untuk mengatasi keterbatasan tersebut masyarakat berhutang kepada rentenir yang rata-rata hal itu justru menambah masalah karena terjerat dengan bunga rentenir. Oleh sebab itu masyarakat memerlukan dukungan untuk mengembangkan diri berdasarkan potensi yang ada di sekitarnya guna menopang perekonomian keluarga terutama saat musim paceklik panen. Untuk merealisaikan dukungan tersebut, cara yang paling tepat adalah dengan melalui pemberdayaan masyarakat.

Melalui sinergi dengan Bank Sampah, pemberdayaan masyarakat di kedua dusun dilakukan dengan mengembangkan pola tanam hidroponik dan pembuatan pupuk yang menunjang pola tanam tersebut. Diharapkan di akhir program, masyarakat mampu menerapkan pola tanam hidroponik dan mengolah sampah sekitar menjadi pupuk. Di tahap selanjutnya hasil panen hidroponik dan pupuk dapat dijual dan dapat mendukung ekonomi keluarga.

Hidroponik merupakan suatu teknik pertanian yang adapat diaplikasikan pada lahan dan waktu yang terbatas (Edwardi, 2017). Hidroponik dapat diaplikasikan untuk menanam baik sayuran maupun bunga. Keuntungan yang diperoleh dengan melakukan pertanian sistem hidropinik antara lain: tidak memerlukan lahan atau pekarangan tanah yang luas, pemberian nutrisi lebih mudah dan efisien, tidak menyebabkan polusi lingkungan, lebih sehat dan bersih (Berberita, 2015). Sehingga pola tanam hidroponik cocok diaplikasikan di kedua mitra.

Sementara itu pembuatan pupuk organik yang berupa pupuk cair dan kompos dari sampah lingkungan sekitar dapat membantu masyarakat memupuk tanaman hidroponik yang dibangun oleh mitra. Sehingga masyarakat tidak perlu membeli pupuk komersil, hal ini menambah efisiensi pada rumah tangga tersebut. Penggunaan pupuk cair telah diteliti sebelumnya bahwa berimbas baik kepada tanaman (Marliah, Hayati, \& Muliansyah, 2012). 
Mempertimbangkan permasalahan yang dihadapi mitra tersebut, maka pengabdian masyarakat ini bertujuan memberikan transfer pengetahuan dan teknologi terkait hidroponik dan pengolahan sampah organik (kompos dan briket).

Berdasarkan observasi yang yang sudah dilakukan maka masalah yang dihadapi oleh mitra adalah kurang stabilnya perekonomian keluarga karena lahan pertanian yang sifatnya semusim. Disisi lain hidroponik adalah paling memungkinkan dilakukan pada lahan yang kering dan dengan suplai air yang minimal seperti di lokasi mitra. Hal itu dikuatkan dengan ketersediaan pupuk organik yang dihasilkan dari sampah lingkungan. Namun demikian keterbatasan teknologi dan pengetahuan mitra dalam dua hal tersebut membuat terbatasnya realisasi hidroponik maupun pengolahan sampah organik, sehingga dalam pengabdian dilakukan transfer teknologi untuk menangani masalah tersebut.

\section{METODE}

Pengabdian masyarakat ini melibatkan dua mitra yaitu kelompok swadaya ibu-ibu yang berasal dari Dusun Soka dan Dusun Jatikuning, Ngoro-oro, Patuk, Gunungkidul. Setiap kelompok terdiri dari 5-7 orang ibu rumah tangga. Kelompok di Jatikuning sudah memiliki Bank Sampah sedangkan Kelompok Soka belum memiliki. Mengacu pada masalah yang dihadapi mitra diatas makan metode pendekatan yang dijalankan pada program ini, yaitu:

\section{Sosialisasi program}

Sosialisasi dilakukan kepada mitra, kepala dusun dan kepala desa di kedua wilayah. Tujuan dari sosialisasi tersebut adalah memberikan penjelasan tujuan, rencana pelaksanaan dan sekaligus serah terima alat (teknologi) yang akan digunakan dalam pendampingan program.

\section{Penyuluhan dan praktek pembuatan} media tanam hidroponik
Penyuluhan ini bertujuan memberikan dasar pemikiran kepada mitra tentang teknik bercocok tanam hidroponik. Pada kesempatan tersebut disampaikan beberapa model bercocok tanam hidroponik beserta alat yang digunakan. Kemudian pada akhir sesi dijelaskan program implementasi hidroponik pada program ini.

\section{Penyuluhan dan praktekpembuatan pupuk organic}

Pada sesi ini diberikan materi pembuatan pupuk organic padat dan cair. Pada sesi ini dijelaskan bagaimana membuat pupuk organi, bahan yang digunakan dan bagaimana mengintegrasikan dengan hidroponik.

\section{Penyuluhan pembuatan briket bioarang}

Pada sesi ini mitra mendapatkan materi pengolahan sampah dalam bentuk lain yaitu pembuatan briket bioarang. Pada materi ini disampaikan cara membuat dan nilai komersil dari briket.

\section{Monitoring dan evaluasi program}

Monitoring dan evaluasi dilakukan pasca pelatihan dan beberapa minggu setelah mitra menerapkan hidroponik dan pengolahan sampah organic. Tujuan kegiatan ini adalah untuk melihat tingkat partisipasi mitra terhadap program dan melihat apakah tahapan yang mereka jalankan sudah sesuai.

\section{HASIL DAN PEMBAHASAN}

Tahapan yang digunakan pada pelaksanaan kegiatan ini adalah:

\section{Sosialisasi program}

Sosialisasi program dilakukan secara bersama antara aparat setempat dengan mitra. Penjelasan program dilakukan melalui presentasi power point oleh tim. Pada sosialisasi ini kepala desa memberikan apresiasi yang tinggi terhadap 
program yang diusung oleh tim dan berharap keberlanjutan program bisa tetap terjamin. Sementara itu mitra antusias dalam mengikuti sosialisasi tersebut. Hal ini terlihat dengan kehadiran seluruh perangkat desa dan mitra dua dusun pada saat sosialisasi.

\section{Penyuluhan dan praktek pembuatan media tanam hidroponik}

Penyuluhan dilakukan secara klasikal atau bersamaan kepada semua mitra. Media yang digunakan adalah powerpoint dan video (audio visual) dengan tujuan memberikan gambaran nyata terhadap apa yang akan dilakukan selama pendampingan program. Video merupakan media efektif untuk transfer pengetahuan dan terbukti efektif. Hal ini sesuai dengan penelitian yang sudah dilakukan sebelumnya walaupun pada topik yang berbeda bahwa penggunaan audio visual pada suatu penyuluhan dapat meningkatkan pengetahuan secara signifikan (Kapti, Rustina, \& Widyatuti, 2013; Saputra, 2016).

Setelah penyuluhan, mitra praktek langsung untuk membuat media tanam hidroponik dengan menggunakan botol bekas air mineral dan beberapa alat penunjang lainnya seperti yang tersaji pada Gambar 3. Ada dua tujuan utama kegiatan ini yaitu pemanfaatan sampah an-organik yaitu botol bekas dan bercocok tanam dengan lahan dan air yang terbatas namun dapat menghasilkan secara ekonomi.

\section{Penyuluhan dan praktek pembuatan pupuk organik}

Pada kegiatan ini diberikan penguatan pengolahan sampah organic dengan teknologi baru yaitu komposter padat dan cair. Teknik diajarkan untuk memberikan pemahaman pengolahan sampah rumah tangga yang dapat berdaya dan berhasil guna. Pupuk cair dapat digunakan untuk pupuk hidroponik dan pupuk padat dapat dijual melalui bank sampah. Dari sampah organicdapat dihasilkan sampah padat maupun sampah cair atau lindi yang dapat dimanfaatkan untuk pupuk bagi tanaman. Dari hasil wawancara singkat dengan mitra, pupuk padat yang mereka hasilkan, sudah laku terjual melalui bank sampah. Sementara itu lindi (pupuk cair) yang dihasilkan sudah diuji coba diaplikasikan ke pohon sawo dan terbukti meningkatkan produktifitas buahnya. Dua hal ini sesuai dengan penelitian sebelumnya yang menyebutkan bahwa kompos padat terbukti dapat berkontribusi pada pertumbuhan tanaman (Augustien \& Hadi, 2002). Hal yang sama juga terbukti pada kompos cair yang dapat memberikan kesuburan pada tanaman (Nur, Noor, \& Elma, 2016).

\section{Penyuluhan pembuatan briket bioarang}

Energi merupakan kebutuhan setiap manusia di bumi ini, seperti contohnya adalah bahan bakar minyak. Namun demikian bahan bakar ini semakin sulit didapat karena sifatnya yang tidak dapat terbarukan. Oleh sebab itu manusia memerlukan alternative energi yang lain. Salah satu alternatif yang dapat diterapkan adalah pemanfaatan bahan-bahan yang sudah tidak terpakai menjadi energi, misalnya pengolahan briket. Briket merupakan suatu alternatif energi terbarukan yang dapat digunakan untuk bahan bakar.

Mitra seperti sudah disebutkan sebelumnya mayoritas bermata pencaharian sebagai petani sehingga mitra memiliki cadangan sekam yang banyak. Oleh sebab itu briket yang dimaksud pada program ini adalah briket yang berasal dari sekam padi. Dari penelitian sebelumnya disebutkan bahwa briket sekam padi memiliki efisiensi termal lebih baik dibanding dengan briket tempurung kelapa (Qistina, Sukandar, \& Trilaksono, 2016) atau dapat dikatakan bahwa briket sekam padi lebih berkualitas dibanding dengan briket tempurung kelapa. 
Pada program ini mitra diberikan alat yang dapat digunakan untuk merubah sekam padi mulai dari pengarangan (Gambar 1), pengadonan (Gambar 2), pencetakan (Gambar 3).

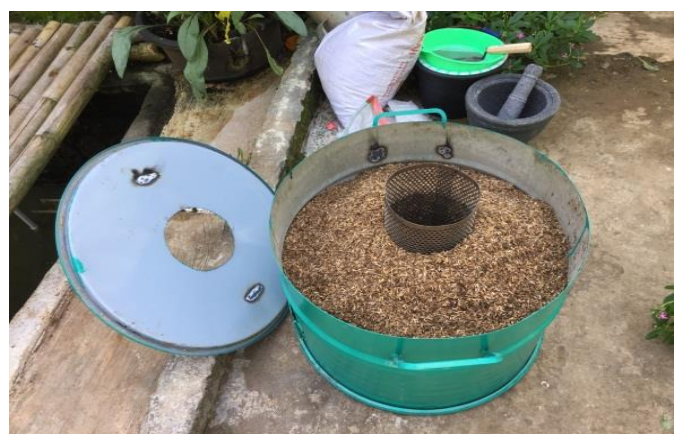

Gambar 1. Proses pengarangan sekam
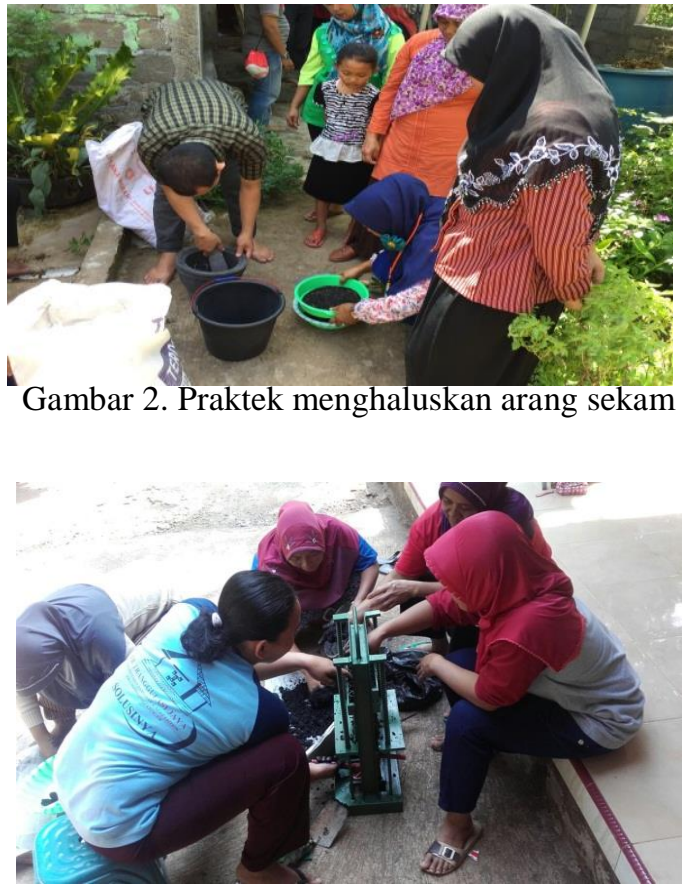

Gambar 3. Praktek pencetakan briket

\section{Monitoring dan evaluasi program}

Monitoring merupakan suatu proses pengawasan untuk melihat perkembangan proses yang direncanakan apakah sesuai dengan prosedur yang sudah ditetapkan atau tidak. Hal ini penting mengingat transfer teknologi dari pengusung ke mitra tidak bisa dilakukan dalam waktu singkat. Sementara itu evaluasi merupakan suatu proses untuk melihat ketercapaian program apakah sesuai dengan tujuan awal program. Dari hasil monitoring dan evaluasi terlihat bahwa prosedur sudah diterapkan dalam praktek mitra paska pelatihan.

Pengabdian masyarakat ini telah berhasil mencapai tujuan yang ditetapkan. Hal ini dapat terlihat dengan pengetahuan dan keterampilan mitra yang meningkat. Hal ini bisa terlihat dengan respon mitra paska kegiatan, dimana mitra selalu menjalin komunikasi ketika mengaplikasikan teknik yang mereka dapatkan ketika pelatihan.

Sebagai kelanjutan program, Kelompok Dusun Soka membentuk Kelompok Bank Sampah di wilayahnya untuk mengatasi permasalahan sampaih di wilayahnya. Sementara itu untuk Kelompok Dusun Jatikuning, dengan berbekal bank sampah yang sudah ada mereka mengembangkan keahlian dengan memproduksi briket, pupuk cair, pupuk padat dan mengembangbiakkan tanaman untuk dijual. Walaupun belum ada angka pasti tentang peningkatan omset namun pihak pengelola bank sampah mengkonfirmasi tentang kenaikan omset tersebut.

\section{SIMPULAN}

Berdasarkan program yang sudah dijalankan dapat disimpulkan bahwa transfer pengetahuan dan keterampilan kepada mitra melalui program ini tercapai. Hal ini terlihat dengan post pelatihan, dimana mitra mampu menerapkan dan memanfaatkan keterampilan tersebut serta berhasil meningkatkan perekonomian walaupun belum diukur secara kuantitatif

\section{DAFTAR PUSTAKA}

Augustien, N., \& Hadi, K. (2002). Peranan Berbagai Komposisi Media Tanam organik terhadap Tanaman Sawi (Brassica juncea L.) di Polybag. Abritop Jurnal-Ilmu Ilmu Pertanian, 
$54-58$.

Berberita. (2015). 10 Keuntungan Menanam Tanaman Hidroponik. Berberita. Retrieved from 29 Juni 2018

Edwardi. (2017, April 1). Inilah Manfaat Bercocok Tanam Hidroponik. Bangka Pos. Retrieved from http://bangka.tribunnews.com/2017/0 4/01/inilah-manfaat-bercocok-tanamhidroponik

Kapti, R. E., Rustina, Y., \& Widyatuti. (2013). Efektifitas Audiovisual sebagai Media Penyuluhan Kesehatan Terhadap Peningkatan Pengetahuan dan Sikap dalam Tatalaksana Balita dengan Diare di Dua Rumah Sakit Kota Malang. Jurnal Ilmu Keperawatan, 1(1), 53-60. http://doi.org/10.1017/CBO97811074 15324.004

Marliah, A., Hayati, M., \& Muliansyah, I. (2012). Pemanfaatan Pupuk Organik Cair Terhadap Pertumbuhan Dan Hasil Beberapa Varietas Tomat (Lycopersicum esculentum L.). Jurnal Agrista, 16(3), 122-128.

Nur, T., Noor, A. R., \& Elma, M. (2016). Pembuatan Pupuk Organik Cair dari Sampah Organik Rumah Tangga dengan Penambahan Bioaktivator EM4 (Effective Microorganisms). Konversi, 5(2), 5-12. http://doi.org/http://dx.doi.org/10.205 27/k.v5i2.1868

Qistina, I., Sukandar, D., \& Trilaksono. (2016). Kajian Kualitas Briket Biomassa dari Sekam Padi dan Tempurung Kelapa. Jurnal Penelitian Dan Pengembangan Ilmu Kimia, 2(2), 136-142.

Saputra, F. A. (2016). Efektivitas media video terhadap peningkatan pengetahuan dan perubahan sikap dalam penyuluhan perikanan budidaya. Institut Pertanian Bogor. 